\title{
Effect of soil water, nitrogen, and growing degree-days on morphological development of crested and western wheat-
} grass

\author{
A.B. FRANK AND R.E. RIES
}

\begin{abstract}
Production of total forage dry matter is mainly a function of available soil water and soil nitrogen $(\mathrm{N})$, whereas plant morphological development from spring greenup to anthesis is primuarily controlled by air temperature. There is a lack of information on effects of soil water and soil $\mathbf{N}$ on plant morphological development. A study was conducted in a rain-out shelter at Mandan, North Dakota, over a 3-year period to determine the effect of 2 fertilizer $N$ rates (11 and $110 \mathrm{~kg} \mathrm{~N} / \mathrm{ha})$ and 3 rates of applied water $(50,100$, and $150 \%$ of long term April-November rainfall at Mandan, North Dakota) on morphological development of initial spring growth and fall regrowth of crested wheatgrass [A gropyron desertorum (Fisch.) Schult] and western whestgrass [Pascopyrum smithii Rydb, (Löve)]. Regression analysis of plant development stage with accumulated growing degree-days (GDD) was linear for both initial and regrowth forage. There were no differences in rate of plant development for the 3 rates of applied water or the 2 rates of $\mathbf{N}$ fertilizer. Initial growth forage of crested and western wheatgrass required 82 and $98 \mathrm{GDD}$ to produce a leaf, respectively. Regrowth forage of crested wheatgrass required 372 and western wheatgrass 135 more GDD than initial growth to produce a leaf.

These data confirm that plants develop primarily in response to air temperature and not added water or $N$, which enhances the utility of using the accumulation of GDD for predicting development of crested and western wheatgrass under different growing conditions. This information will be useful for predicting plant development of these species in growth models and for farmers and ranchers in predicting grazing readiness.
\end{abstract}

Key Words: growing degree-days, forages, grasses, Pescopyrum smithii, Agropyron desertorum

\footnotetext{
Authors are plant physiologist and range scientist, USDA-ARS, P.O. Box 459, Mandan, North Dakota 58554

This article is a contribution from USDA, Agricultural Research Service, Mandan, North Dakota.

Manuscript accepted 28 June 1989.
}

Forage production of rangeland grasses is enhanced primarily through antecedent soil water, seasonal precipitation events, availabie nutrients, especialiy $\mathbf{N}$, and management (Rogier and Haas 1947 , Smika et al. 1965, and Sneva 1977). The rate of forage growth during the early part of the growing season is also strongly influenced by air temperature. Numerous reports have followed the rate of morphological development of plants in response to air temperature or heat units expressed as growing degree-days (GDD) (Bauer et al. 1984, Frank et al. 1985, Wang 1960, and Robertson 1968). These reports suggest that water, nutrients, and management determine quantity of dry matter produced, whereas air temperature determines timing of plant development. However, information is lacking on the effects of water and $N$ on the relationship between plant morphological development and GDD, especially for forage grasses.

Wang (1960) provided an extensive review on the history of heat unit accumulation and plant development research and application. Recent reports have shown that plant morphological development is strongly related to air temperature in corn (Zea mays $\mathrm{L}$.) (Bunting 1976 and Cross and Zuber 1972); spring wheat (Triticum aestivum L.) (Bauer et al. 1984 and Davidson and Campbell 1983); and several native and introduced forages including crested wheatgrass [ Agropyron desertorum (Fisch.) Schult.], intermediate wheatgrass [ Thinopyrum intermedium (Host) Barkw. and D.R. Dewey subsp. intermedium], western wheatgrass [Pascopyrum smithii Rydb, (Löve)], reed canary grass (Phalaris arundinacea L.), blue grama [Bouteloua gracilis (H.B.K.) Lag. ex Griffiths], prairie junegrass [Koeleria pyramidata (Lam.) Beauv.], needleandthread (Stipa comata Trin. and Rupr.), and green needlegrass ( $S$. viridula Trin.) (Frank et al. 1985 and Frank and Hofmann 1989).

The objectives of this study were to determine the effects of 
applied water and $\mathrm{N}$ fertilizer on the relationship between plant morphological development and GDD for crested and western wheatgrass. Determining the effects of applied water on plant development will provide information in relation to both drought and high rainfall years, whereas the $\mathrm{N}$ along with the water variable will provide conditions for testing the GDD concept under increased forage production potential.

\section{Materials and Methods}

Cultivars 'Rodan' western wheatgrass and 'Nordan' crested wheatgrass were seeded into a clean seedbed in a rain-out shelter (Ries and Zachmeier 1985) at Mandan, N. Dak., on 22 August 1983. The seeding was irrigated using an overhead sprinkler system to enhance establishment. The soil was a Parshall fine sandy loam (Pachic Haploborolls). Three replications of plots $(2.1 \times 3.1 \mathrm{~m})$ were established under the rain shelter in a split-split plot arrangement. Main plots were 3 soil water levels established by applying water weekly with overhead sprinklers from 1 April to 1 November. The amount of water applied monthly for each treatment was 50 , 100 , and $150 \%$ of the long term 1 April to 1 November precipitation of $336 \mathrm{~mm}$ (Table 1). The plots were protected from natural precip-

Table 1. Amount of water applied each month to plants to give 50,100, and $150 \%$ of average rainfall from April through Oetober.

\begin{tabular}{lccc}
\hline & \multicolumn{3}{c}{ Percent of average rainfall } \\
\cline { 2 - 4 } Month & 50 & 100 & 150 \\
\hline & 16 & 32 & 48 \\
April & 27 & 54 & 81 \\
May & 42 & 84 & 126 \\
June & 31 & 61 & 92 \\
July & 22 & 43 & 65 \\
August & 19 & 38 & 57 \\
September & 12 & 24 & 36 \\
October & 169 & 336 & 505 \\
$\quad$ Total & & &
\end{tabular}

itation from 1 April through 1 November by covering with an automatic rain-out shelter. The rain-out shelter was not operated from 1 November to 1 April, which allowed the plots to be exposed to natural winter weather. Subplots were $\mathrm{N}$ fertilizer applied at 11 and $110 \mathrm{~kg} \mathrm{~N} /$ ha about 1 April each year. Plant morphological development was determined on 10 plants per plot 3 times weekly from beginning of plant development in the spring to seed soft dough formation and on regrowth plants from beginning of development following clipping to cessation of development in October each year using the Haun (1973) scale. The Haun scale is a numerical expression of growth based on the number of leaves produced and on spike development. Growing degree-days (GDD) were calculated from minimum and maximum air temperature, measured hourly at $1 \mathrm{~m}$ height above an adjacent clipped grass area, with a base temperature of $0^{\circ} \mathrm{C}$. Accumulation of GDD was started on the first day after $15 \mathrm{March}$ that the average daily air temperature exceeded $0^{\circ} \mathrm{C}$ for 5 consecutive days at Mandan, $N$. Dak. Soil water potential was measured weekly in each plot using thermocouple psychrometers placed at $45 \mathrm{~cm}$ depth. Psychrometer readings were corrected to a $25^{\circ} \mathrm{C}$ base temperature. Leaf water potential of the top most fully developed leaf, excluding the flag leaf, was measured during the initial growth period at 1300 to 1400 hours on clear days using thermocouple psychrometers for 11,13 , and 12 days in 1984,1985, and 1986, respectively. Total forage dry matter was sampled by hand clipping $0.2-\mathrm{m}^{2}$ areas at $5-\mathrm{cm}$ stubble at seed soft dough each year and dried at $70^{\circ} \mathrm{C}$. The study was conducted over a 3-year period, 1984, 1985, and 1986. Statistical analysis was conducted using the SAS General Linear Models procedures for analysis of variance and regression analysis (SAS
Table 2. Average of weekly soil water potentials measured at $45 \mathrm{~cm}$ soil depth during 1984, 1985, and 1986 for crested and western wheatgrass grown at 50,100 , and $150 \%$ of average April through October rainfall.

\begin{tabular}{|c|c|c|c|c|c|}
\hline \multirow[b]{2}{*}{ Species } & \multirow{2}{*}{$\begin{array}{l}\text { Percent of } \\
\text { avg. rainfall } \\
\text { April-October }\end{array}$} & \multicolumn{4}{|c|}{ Soil water potential } \\
\hline & & 1984 & 1985 & 1986 & Mean \\
\hline $\begin{array}{l}\text { Crested } \\
\text { wheatgrass }\end{array}$ & $\begin{array}{c}\% \\
50 \\
100 \\
150 \\
\text { F-test: water } \\
\text { F-test: water*date }\end{array}$ & $\begin{array}{l}-0.37 \\
-0.30 \\
-0.21 \\
* * \\
* *\end{array}$ & $\begin{array}{l}-.-1 \\
-0.59 \\
-0.47 \\
-0.31 \\
* * \\
* *\end{array}$ & $\begin{array}{c}P a-\ldots \\
-0.57 \\
-0.43 \\
-0.10 \\
*\end{array}$ & $\begin{array}{l}-0.51 \\
-0.40 \\
-0.20\end{array}$ \\
\hline $\begin{array}{l}\text { Western } \\
\text { wheatgrass }\end{array}$ & $\begin{array}{c}50 \\
100 \\
150 \\
\text { F-test: water } \\
\text { F-test: water*date }\end{array}$ & $\begin{array}{l}-0.17 \\
-0.15 \\
-0.14 \\
\text { NS } \\
\text { NS }\end{array}$ & $\begin{array}{l}-0.36 \\
-0.31 \\
-0.22 \\
\text { NS } \\
* *\end{array}$ & $\begin{array}{c}-0.37 \\
-0.29 \\
-0.09 \\
* \\
* *\end{array}$ & $\begin{array}{l}-0.31 \\
-0.26 \\
-0.15\end{array}$ \\
\hline
\end{tabular}

*,** Indicate significance at $P \leq 0.05$ and 0.01 , respectively. NS indicates nonsignificant at $P \leq 0.05$.

Institute, Inc., 1985).

\section{Results and Discussion}

Soil water potentials increased as amount of applied water increased from 50 to $150 \%$ for all 3 years (Table 2). Soil water potential at $45 \mathrm{~cm}$ depth showed a water treatment $X$ date interaction each year for crested wheatgrass and in 1985 and 1986 for western wheatgrass. There was a trend indicating that crested wheatgrass extracted water to a lower soil water potential than western wheatgrass at the same rate of water application. Leaf water potentials increased as soil water potentials and rate of applied water increased for both species (Table 3). As applied

Table 3. Leaf water potential at 1300 hrs for crested and western wheatgrass grown at 50, 100, and 150\% percent of average April through October rainfall. Data are for 11, 13, and 12 days in 1984, 1985, and 1986.

\begin{tabular}{|c|c|c|c|c|c|}
\hline \multirow[b]{2}{*}{ Species } & \multirow{2}{*}{$\begin{array}{l}\text { Percent of } \\
\text { avg. rainfall } \\
\text { April-October }\end{array}$} & \multicolumn{4}{|c|}{ Leaf water potential } \\
\hline & & 1984 & 1985 & 1986 & Mean \\
\hline & $\%$ & \multicolumn{4}{|c|}{$\ldots \ldots-\ldots$} \\
\hline $\begin{array}{l}\text { Crested } \\
\text { wheatgrass }\end{array}$ & $\begin{array}{c}50 \\
100 \\
150 \\
\text { F-test: water } \\
\text { F-test: water } X \text { date }\end{array}$ & $\begin{array}{c}-3.4 \\
-3.3 \\
-2.9 \\
* * \\
\text { NS }\end{array}$ & $\begin{array}{c}-3.5 \\
-3.4 \\
-3.3 \\
\text { NS } \\
\end{array}$ & $\begin{array}{c}-3.6 \\
-3.3 \\
-2.9 \\
* \\
*\end{array}$ & $\begin{array}{l}-3.5 \\
-3.3 \\
-3.0\end{array}$ \\
\hline $\begin{array}{l}\text { Western } \\
\text { wheatgrass }\end{array}$ & $\begin{array}{c}50 \\
100 \\
150 \\
\text { F-test: water } \\
\text { F-test: water } X \text { date }\end{array}$ & $\begin{array}{l}-2.9 \\
-2.8 \\
-2.6 \\
\text { NS } \\
\text { NS }\end{array}$ & $\begin{array}{l}-3.1 \\
-3.0 \\
-2.9 \\
\text { NS } \\
\text { NS }\end{array}$ & $\begin{array}{l}-3.3 \\
-3.1 \\
-2.8 \\
\text { NS } \\
\text { NS }\end{array}$ & $\begin{array}{l}-3.1 \\
-3.0 \\
-2.8\end{array}$ \\
\hline
\end{tabular}

*,** Indicate significance at $P \leq 0.05$ and 0.01 , respectively. NS indicates nonsignificant at $P \leq 0.05$.

water increased from 50 to $150 \%$, the trend was for leaf water potentials to increase for both species, although not significantly for western wheatgrass. Statistical comparisons were not made between species, but crested wheatgrass exhibited lower leaf water potentials than western wheatgrass for every water treatment, which follows the trend of lower soil water potential for crested wheatgrass.

Total dry matter for both crested and western wheatgrass was affected by applied water and $\mathrm{N}$ fertilizer (Table 4). There was a significant $\mathrm{N}$ effect and a $\mathrm{N} \times$ water interaction for crested wheatgrass. At the $11 \mathrm{~kg} \mathrm{~N} /$ ha rate, crested wheatgrass dry matter yields were similar at all 3 water levels, but at the $110 \mathrm{~kg} \mathrm{~N} /$ ha rate, yields 
Table 4. Forage dry matter production for crested and western wheatgrass during 1984, 1985, and 1986 when grown at 11 and $110 \mathrm{~kg} \mathrm{~N} / \mathrm{ha}$ and 50 , 100 , and $150 \%$ of average April through October rainfall.

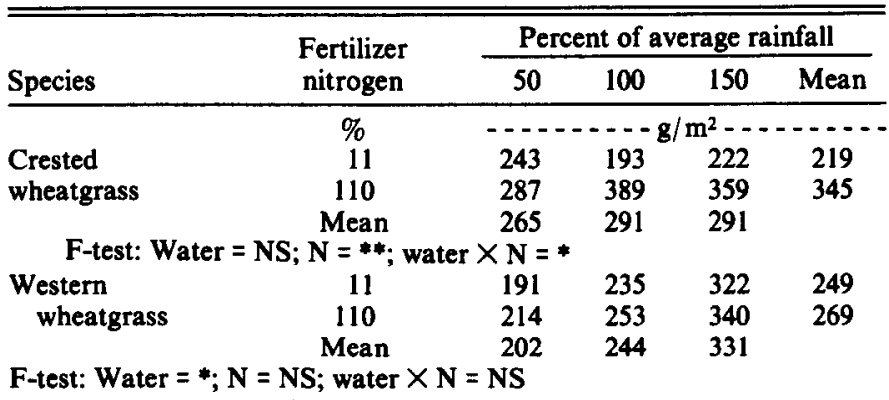

*,** Indicate significance at $P \leq 0.05$ and 0.01 , respectively. NS indicates nonsignificant at $P \leq 0.05$.

were greater at the 100 and $150 \%$ water level. Dry matter yields of western wheatgrass increased significantly as applied water increased from 50 to $150 \%$. There were no differences in western wheatgrass dry matter yields in response to the 2 rates of applied $\mathbf{N}$ fertilizer, nor was there a significant $\mathbf{N} \times$ water interaction. Crested wheatgrass produced more dry matter in response to $N$, whereas western wheatgrass produced more dry matter in response to applied water levels.

The results presented in Tables 2, 3, 4 show that the water and $N$ treatments produced sufficiently different growth conditions over the 3 years to determine if these variables differently affected morphological development of crested and western wheatgrass as related to accumulated GDD. Regression analysis of Haun stage versus accumulated GDD, conducted on all subset combinations of water and $\mathbf{N}$, produced similar regression coefficients. Regression coefficients ranged from 0.1171 to 0.1253 and 0.0101 to 0.0103 for initial growth crested wheatgrass and western wheatgrass, respectively, and from 0.0023 to 0.0026 and 0.0039 to 0.0050 for regrowth crested wheatgrass and western wheatgrass, respectively. The $r$ values were high and ranged from $0.98-0.99$ and $0.87-0.93$ for initial spring and regrowth forage for both species, respectively. As a result of the uniform regression coefficients and high $r$ values, the data were combined for all years and treatments to provide a single relationship for plant development and accumulated GDD. Plant morphological development recorded as Haun stage was linearly related to accumulated GDD over the 3 years for both species and growth periods (Figs. 1 and 2). Both species produced 6

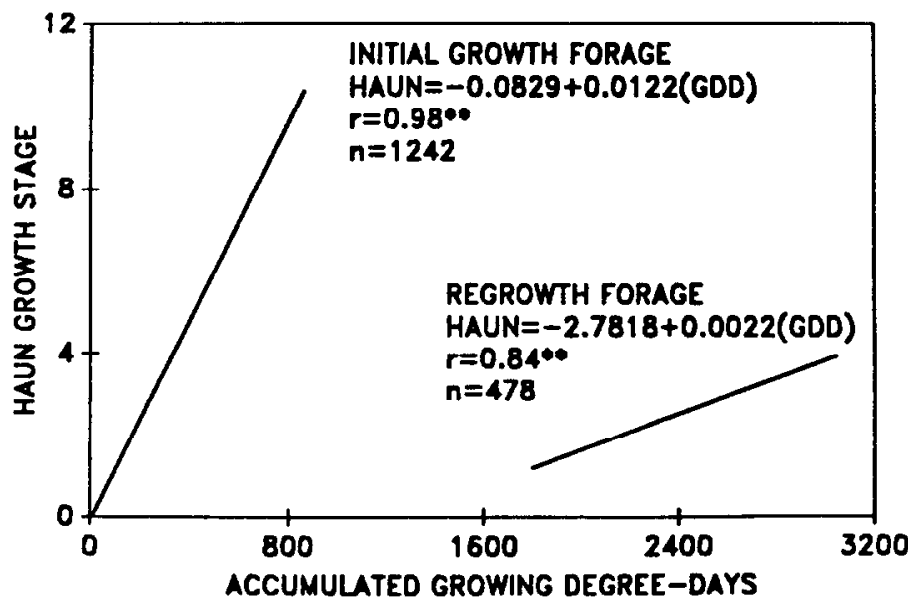

Fig 1. Regression of Haun growth stage and accumulated growing degreedays for initial spring growth and regrowth forage of crested wheatgrass during 1984, 1985, and 1986. The average date to accumulate 800,1600 , and 2400 growing degree-days was 6 June, 7 July, and 28 August, respectively,

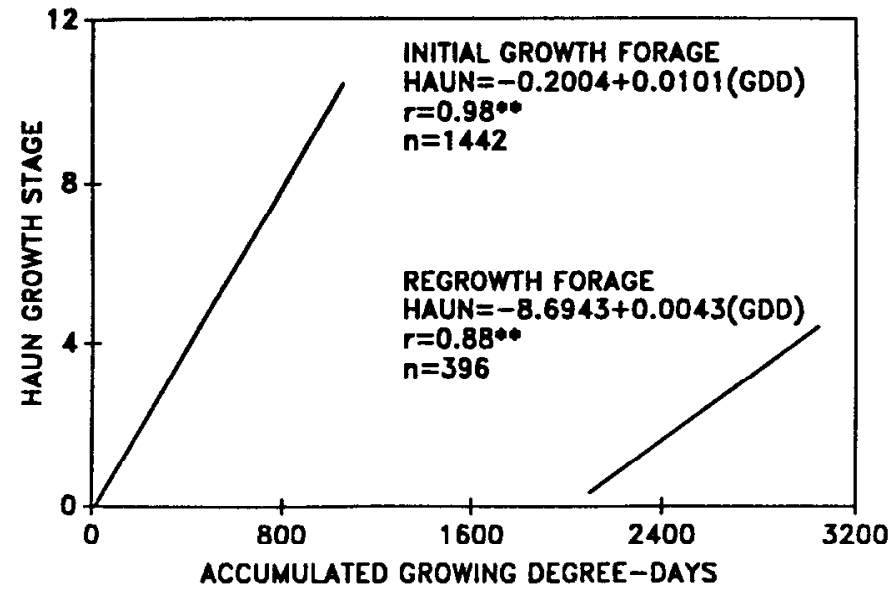

Fig. 2. Rezression of Haun growth stage and accumulated growing degreedays for initial spring growth and regrowth forage of western wheatgrass during 1984, 1985, and 1986. The average date to accumulate 800,1600 , and 2400 growing degree-days was 6 June, 7 July, and 28 August, respectively.

leaves (Haun stage 6) with a few western plants producing 7 leaves. The combined regression across years and treatments for initial and regrowth forage indicates that morphological development is a function of accumulated GDD and is not a function of water or $\mathbf{N}$ levels. Based on these regression equations, initial development of crested wheatgrass required 82 GDD and western wheatgrass 98 GDD to produce each leaf.

Plant development during the regrowth phase for both species was determined after regrowth had about 1 leaf which occurred after about 2,000 GDD had accumulated during each season (Figs. 1 and 2). Regrowth plants did not produce more than 4 leaves, probably due to lower temperatures and decreasing photoperiods. The combined regression between Haun stage and accumulated GDD for the regrowth plants (crested wheatgrass, $r=0.84$, and western wheatgrass $r=0.88$ ) was not as good a fit as for initial growth development. Based on the combined regression equations, regrowth of crested wheatgrass required 454 GDD and western wheatgrass 233 GDD to produce each leaf. Comparing initial and regrowth data showed that there was a different GDD requirement for both species to produce a leaf. Crested wheatgrass required 372 more GDD to produce a leaf during regrowth compared to initial spring growth, whereas, western wheatgrass required only 135 additional GDD.

The results of this study correspond well with other results for forage grasses (Frank et al. 1985 and Frank and Hofmann 1989) and other crops (Bauer et al. 1984, Bunting 1976, Cross and Zuber 1972, Davidson and Campbell 1983) which show air temperatures as the primary driving force controlling morphological development in plants. Although productivity of crested wheatgrass and western wheatgrass was generally enhanced by water or $\mathbf{N}$, morphological development of each species was similar for both water and $\mathbf{N}$ treatments during the 3-year study. Visual observations indicated thinning of plant population as water level decreased, but the $50 \%$ rate of applied water was not below the threshold level necessary to affect plant morphological development. These results, and those of a prior study showing that grazing management practices did not affect plant development, strengthen the utility of using accumulated GDD in rangeland growth models and as a guide for initiation of grazing based on plant development stage compared to calendar date. 


\section{Literature Cited}

Bauer, A., A.B. Frank, and A.L. Black. 1984. Estimation of spring wheat leaf growth rates and anthesis from air temperature. Agron. J. 76:829-835.

Bunting, E.S. 1976. Accumulated temperature and maize development in England. J. Agr. Sci. Camb. 87:577-583.

Cross, H.F., and M.S. Zuber. 1972. Prediction of flowering dates in maize based on different methods of estimating thermal units. Agron. J. 64:351-355.

Davidson, H.R., and C.A. Campbell. 1983. The effect of temperature, moisture and nitrogen on the rate of development of spring wheat as measured by degree days. Can. J. Plant Sci. 63:833-846.

Frank, A.B., J.D. Berdahl, and R.E. Barker. 1985. Morphological development and water use in clonal lines of four forage grasses. Crop Sci. 25:339-344.

Frank, A.B., and L. Hofmann. 1989. Relationship among grazing management, growing degree-days, and morphological development for native grasses on the northern Great Plains. I. Range Manage. 42:199-202.

Haun, J.R. 1973. Visual quantification of wheat development. Agron. J. 6.5.116-119
Ries, R.E., and L.C. Zachmeier. 1985. Automated rainout shelter for controlled water research. J. Range Manage. 38:353-357.

Robertson, G.W. 1968. A biometeorological time scale for a cereal crop involving day and night temperatures and photoperiod. Int. J. Biometeorol. 12:191-223.

Rogler, G.A., and H.J. Haas. 1947. Range production as related to soil moisture and precipitation on the Northern Great Plains. Agron. J. 39:378-389.

SAS Institute, Inc. 1985. SAS user's guide: Statistics. Version 5 Edition, Cary, NC. SAS Institute, Inc.

Smika, D.E., H.J. Haas, and J.F. Power. 1965. Effects of moisture and nitrogen fertilizer on growth and water use by native grass. Agron. J. 57:483-486.

Sneva, F.A. 1977. Correlations of precipitation and temperatures with spring, regrowth, and mature crested wheatgrass yields. J. Range Manage. 30:270-275

Wang, Jen Yu. 1960. A critique of the heat unit approach to plant response studies. Ecology 41:785-790. 